\title{
ECONOMIC IMPACT OF THE WILLIAMSON ACT IN SAN LUIS OBISPO COUNTY
}

\author{
A Thesis \\ presented to \\ the Faculty of the Agribusiness Department \\ California Polytechnic State University, San Luis Obispo
}

\begin{abstract}
In Partial Fulfillment
of the Requirements for the Degree

Master of Science in Agribusiness
\end{abstract}

by

Hayley Nicole Loehr

August 2012 
(C) 2012

Hayley Nicole Loehr ALL RIGHTS RESERVED 


\section{COMMITTEE MEMBERSHIP}

TITLE:

Economic Impact of the Williamson Act in San Luis Obispo County

AUTHOR:

Hayley Nicole Loehr

DATE SUBMITTED: August 2012

COMMITTEE CHAIR: $\quad$ Dr. Lynn Hamilton, Professor, Agribusiness Department

COMMITTEE MEMBER: $\quad$ Dr. Marcia Tilley, Professor, Agribusiness Department

COMMITTEE MEMBER: Dr. Richard Thompson, Professor, Natural Resources Management and Environmental Sciences Department 


\begin{abstract}
Economic Impact of the Williamson Act in San Luis Obispo County Hayley Nicole Loehr
\end{abstract}

The goal of this research was to analyze the economic impact of the Williamson Act and the agricultural industry in San Luis Obispo County, and to assess the changes in agriculture and the County's economic structure if a significant proportion of Williamson Act contracts were not renewed. Williamson Act enrollment and agriculture data were analyzed on a zip code level using IMPLAN v. 3.0, an input-output modeling program.

The first round of analysis assessed the baseline economic impact of the agriculture industry in San Luis Obispo County. Then, four regions of the county were established based on Williamson Act enrollment and similarities in agricultural production to provide a more accurate reflection of the potential changes to the local economy. The results were reflected in changes to direct sales, total sales, total income, total value added and number of jobs lost.

The study concluded that removing the Act's funding would have very little impact on land use in the county because of the strict agricultural zoning, but may affect the financial strength of agriculture operations depending on their reliance on the tax incentive. Although this study predicts minor decreases in agricultural output if the Williamson Act was removed, the anticipated economic impacts of the lost output are far greater than the costs to maintain the funding for the Act. The direct cost of the Williamson Act to San Luis Obispo County is roughly $\$ 3$ million per year, yet if the Act is eliminated, it is estimated $\$ 14$ to $\$ 39$ million will be lost in county-wide agricultural output. 


\section{ACKNOWLEDGMENTS}

I will never be able to thank the many people - faculty, mentors, family, and friends - enough for all of their guidance and encouragement through this process. I especially want to thank Dr. Hamilton for letting me be a part of an issue I am passionate about. Dr. Hamilton, I am constantly challenged and inspired by your knowledge and work ethic. I will always be in debt to you for ruining my enjoyment of keynote speeches.

The Sinton family deserves considerable credit for the success of this project. Their dedication to San Luis Obispo County and passion for the agriculture industry are undeniable. I feel incredibly fortunate to have had the opportunity to work with such dedicated people.

I owe a debt of gratitude to Dr. Noel and Dr. Ahern of the Agribusiness department. Both were supporters to me throughout my academic career. I owe much thanks to Craig Hooper for being a mentor to me and always acting as a voice of reason. The endless support of the Agribusiness department is the reason I have succeeded as a student.

I want to thank my colleagues at Farm Credit West who were equally as excited for me to finish my masters. I am so lucky to be surrounded by such supportive, intelligent, and caring people.

I am grateful to my parents, Nick and Taryn, for teaching me the value of learning and education. Thank you for standing behind every effort I have undertaken and for your endless commitment and pride in me through failure and achievement. 


\section{TABLE OF CONTENTS}

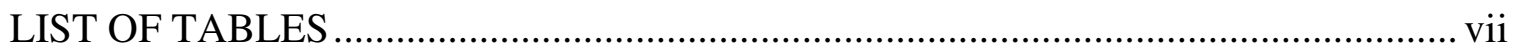

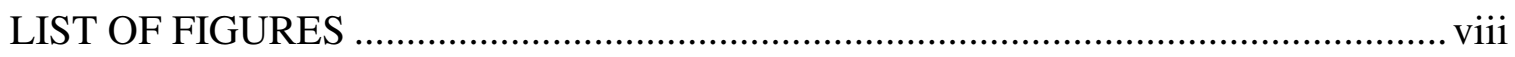

CHAPTER

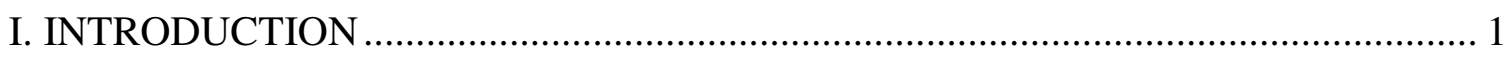

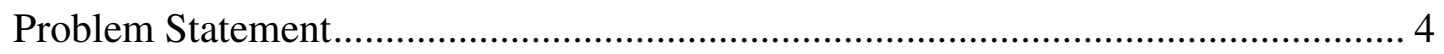

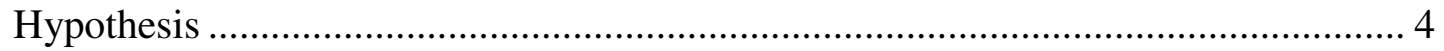

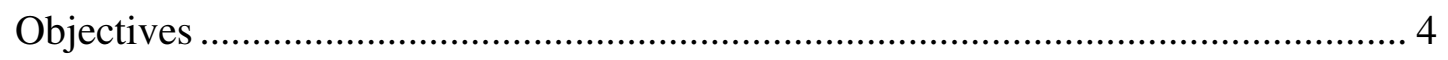

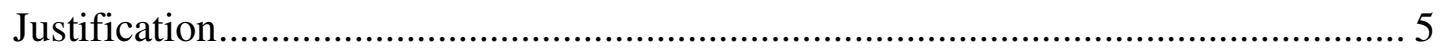

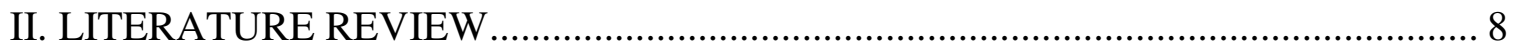

Understanding the Williamson Act .................................................................... 8

Land Conversion in California ............................................................................. 12

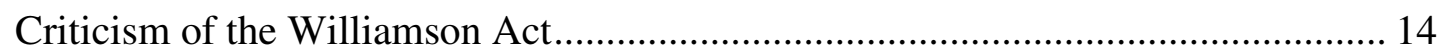

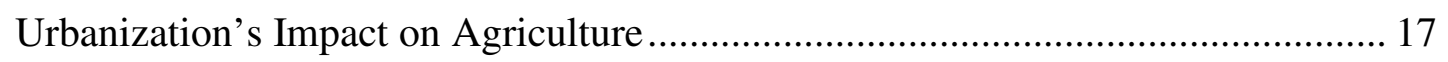

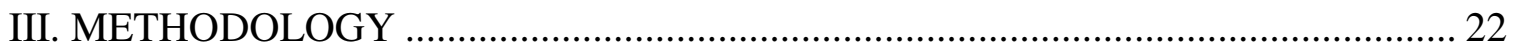

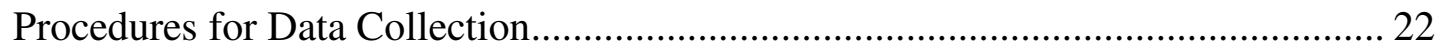

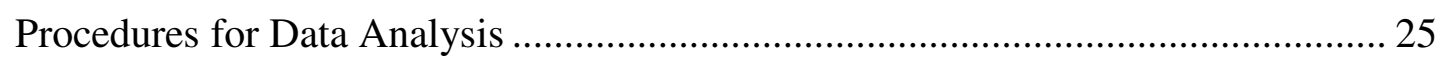

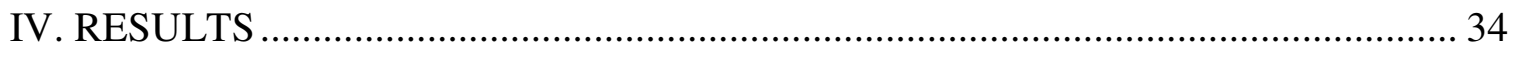

V. SUMMARY, CONCLUSIONS AND RECOMMENDATIONS................................ 44

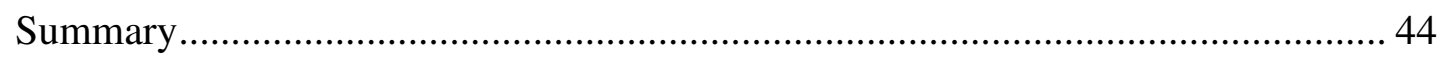

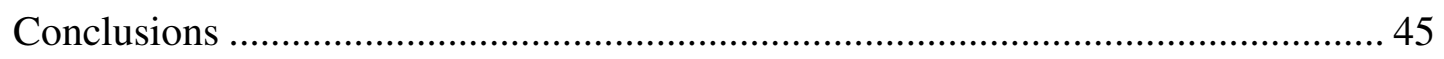

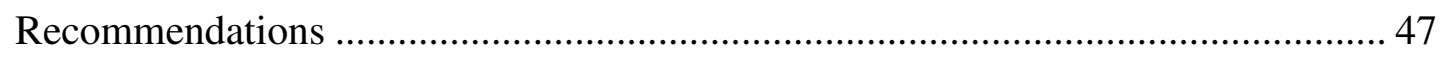

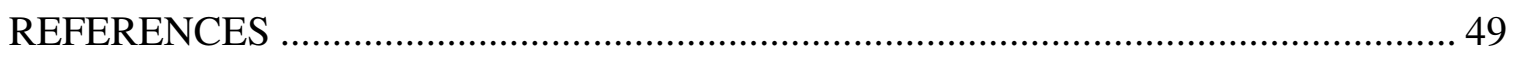

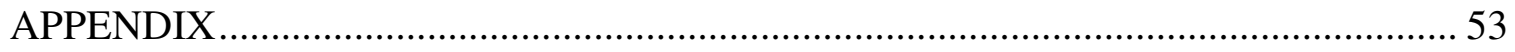

Appendix A: Key Milestones in the Williamson Act's History .................................... 53

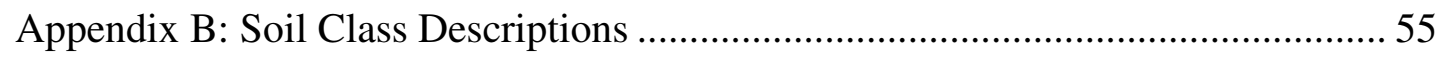




\section{LIST OF TABLES}

Table 1: Land Use Conversion in San Luis Obispo County from 2006-2008 (Acres)..... 13

Table 2: Williamson Act Enrollment by Prime and Non-Prime Land............................ 13

Table 3: IMPLAN Multipliers by Commodity ........................................................ 26

Table 4: UC Davis Cost of Production Studies-Property Taxes Analysis...................... 31

Table 5: IMPLAN Adjustments to Output by Commodity ........................................... 33

Table 6: Summary Analysis of Agriculture in San Luis Obispo County ........................ 35

Table 7: Total Effects of Agriculture in San Luis Obispo County ................................. 36

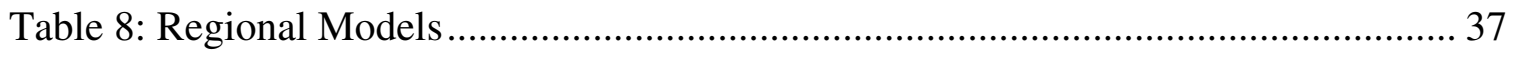

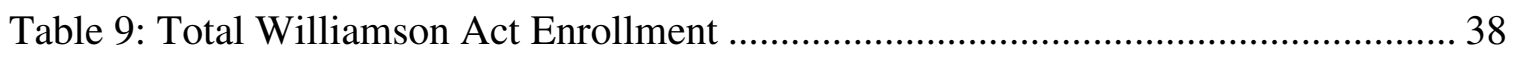

Table 10: Impact Summary San Luis Obispo County Low Scenario............................. 39

Table 11: Impact Summary San Luis Obispo County High Scenario ............................ 39

Table 12: Impact Summary North Coast Low Scenario ............................................ 40

Table 13: Impact Summary North Coast High Scenario ........................................... 40

Table 14: Impact Summary North East Low Scenario .......................................... 41

Table 15: Impact Summary North East High Scenario ............................................ 41

Table 16: Impact Summary South Coast Low Scenario ............................................. 41

Table 17: Impact Summary South Coast High Scenario .......................................... 42

Table 18: Impact Summary South East Low Scenario ............................................ 42

Table 19: Impact Summary South East High Scenario .............................................. 43

Table 20: Summary IMPLAN Results by Region ................................................... 45 


\section{LIST OF FIGURES}

Figure 1: San Luis Obispo County Williamson Act Parcels and Zoning..............28 


\section{CHAPTER I}

\section{INTRODUCTION}

In the past 25 years, California has experienced major land-use changes. As urbanization continues to spread, the competition between agricultural and nonagricultural uses is likely to increase (Barnard and Lucier, 1998). From 1984 to 2008, California's farm and grazing land decreased by 1.3 million acres, averaging 55, 100 acres lost per year. Of the land taken out of production, 1.04 million acres were urbanized. Prime farmland ${ }^{1}$, land with the highest soil quality for agriculture production, experienced the largest reduction in this time, with losses of around 560,000 acres. The other major causes for land conversion were low-density rural residences, mining, and environmental recovery projects (California Department of Conservation, 2011). The 2011 California Farmland Conversion Summary reported 64 percent of California's land as designated for agricultural purposes in 2008. Only seven percent, roughly 3.6 million acres, of total land was urban or built-up land (Brown, 2011). Due to increased efficiency levels and changes in commodities produced, urbanization has made little, if any, impact on California's total agriculture output. Nevertheless, as the population continues to grow and technology, consumer demand, and land prices change, the long-term effects of urbanization may become more significant (Sokolow and Kuminoff, 2000).

\footnotetext{
${ }^{1}$ According to the Farmland Mapping and Monitoring Program, prime farmland and farmland of statewide importance is land used for irrigated agriculture during the past four years and possesses a high soil quality determined by the USDA Natural Resources Conservation Services.
} 
Concerns about farmland loss began during the post-World War II period, as California's population started to grow rapidly. This growth directly affected land as entrepreneurs expanded their property holdings to profit from the growing population demands. As landowners began developing their property in hopes of financial success, valuable farmland continued to disappear. In response to the alarming land conversion pressures, the California State Assembly created an interim committee and expert advisory committee to develop a solution. The result was Assembly Bill (AB) 2117, which legislated the California Land Conservation Act of 1965, later referred to as the Williamson Act as a tribute to its author, John Williamson (California Department of Conservation: Basic Contract Provisions, 2007). The Act is an arrangement among three parties: state government, county government, and private landowners. Regulated and controlled at the county level, landowners enter voluntary agreements with the county to receive discounted property taxes in exchange for a ten-year commitment not to develop their land. In its original form, the state would reimburse the county for the revenues lost from forgone property taxes, through Open Subvention Payments (Diaz and Detwiler, 2010).

Maintaining the Williamson Act has become increasingly difficult as the State struggles to meet its budget responsibilities. Governor Schwarzenegger's 2003-04 budget was the first movement towards the elimination of the act when the Legislative Analyst's Office (LAO) recommended a ten-year phase-out (Diaz and Detwiler, 2010). The first cut to the act was in 2008-09 when Schwarzenegger signed AB 1389, a "trailer bill" that mandated the State Controller to reduce county space subventions by $10 \%$. The $2009-10$ annual budget reduced appropriations for direct subventions to $\$ 1,000$ per county. On 
March 24, 2011, Governor Brown began his efforts to remove the Williamson Act by approving Senate Bill 80, which eliminated Senate Bill 863. Senate Bill 863 provided participating counties a substitute to exiting the Williamson Act by distributing a onetime $\$ 10$ million subvention and a provision to reclaim $10 \%$ of the lost property tax revenue (Senate Bills 863 and 80 Updated Advisory Statement, 2011). On May 27, 2011, only two months after Brown approved Senate Bill 80, Assemblyman Jim Nielsen proposed Assembly Bill 1265. The bill passed unanimously in both chambers and the Governor approved it on July 13, 2011 (Hansen, 2011). This bill essentially reinstated the language passed in 2010 to restore the $10 \%$ reduction in contract length and $10 \%$ decrease in tax breaks, but did not include the $\$ 10$ million subvention funding. Only counties that received less than half of their foregone property tax revenue from the Open Space Subvention Act fund in 2009 are eligible to adopt the new provisions (California Department of Conservation, 2011). Essentially, the bill does not have any funding attached to it, meaning it does not commit any additional state resources (Hansen, 2011).

San Luis Obispo County is one of the 54 counties in the state grappling with the decision to maintain the Williamson Act. There are 1.16 million acres of agricultural land in San Luis Obispo County with 1.13 million acres currently being harvested (San Luis Obispo Chamber of Commerce, 2011). Within the county 791,023 acres are enrolled in the Williamson Act, accounting for roughly 68 PERCENT of the county's agricultural land and 35 percent of total land. In 2009, San Luis Obispo County ranked the $10^{\text {th }}$ largest beneficiary of subvention payments, collecting roughly $\$ 1,088,726$. According to the 2010 Status Report on the Williamson Act, San Luis Obispo experienced the fourth largest growth in enrollment from 2007 to 2008, with an increase of 5,520 acres. 
However, in 2009 San Luis Obispo County had the greatest number of nonrenewal initiations with 4,601 acres. Nonrenewals are typically filed when property owners intend to convert farmland to other uses. In 2009, San Luis Obispo County experienced a net decrease of 3,122 acres in enrollment (California Department of Conservation, 2011).

\section{$\underline{\text { Problem Statement }}$}

The goal of this report is to analyze the economic impact of the Williamson Act and the agricultural industry in San Luis Obispo County, and to assess the changes in agriculture and the County's economic structure if a significant proportion of Williamson Act contracts were not renewed.

\section{$\underline{\text { Hypothesis }}$}

The economic benefits generated from land protected by the Williamson Act are greater than, or equal to property tax revenues lost from participation in the Act.

\section{$\underline{\text { Objectives }}$}

1) To quantify the economic impact of the agricultural industry in San Luis Obispo County.

2) To determine the extent of agriculture production lost if San Luis Obispo County did not renew its Williamson Act contracts.

3) To quantify the net impact on San Luis Obispo's economy if a significant number of Williamson Act contracts were not renewed and agriculture production was lost. 


\section{$\underline{\text { Justification }}$}

Currently, 15 million acres—roughly fifty percent of California's 30 million acres of agriculture land-are enrolled in Williamson Act. Of the 15 million acres, 14.1 million are eligible for open space subvention payments (California Department of Conservation, 2010). Only Del Norte, San Francisco, Inyo, and Yuba counties have not adopted the act. Studies show that landowners with agriculture parcels enrolled in the Williamson Act and Farmland Security Zone (FSZ) programs pay 83 percent less in property taxes per year (California Department of Conservation, 2010). Several conservation programs are available to agriculture landowners in California, and equate to over $\$ 400$ million a year in benefits. The Williamson Act accounts for more than $\$ 300$ million per year because of the estimated property tax savings farmers and ranchers receive. In addition to the $\$ 300$ million, the state government typically distributes around $\$ 39$ million per year to counties as a fractional reimbursement for their legislatively reduced property taxes (Sokolow and Bennett, 2004). Since 1972, the State General Fund has distributed roughly $\$ 875$ million in direct subventions to county governments participating in the program. Participation in the program has only increased due to rising labor and energy costs and strain on resources. Subvention payments have also experienced a steady growth rate; in 1972-73, the state paid $\$ 8.8$ million dollars, in 1990-91, subventions reached $\$ 13.6$ million, and by 2005-2006 \$38.7 million was distributed (Diaz and Detwiler, 2010). In 2009, involved local governments claimed \$35,107,597 in Open Space Subventions payments (California Department of Conservation, 2010). 
San Luis Obispo County's large and diverse agriculture industry is a significant part of the local economy, making it vital to understand the impact of the potential loss of California's largest farmland preservation policy. The State government has agreed to salvage the act but has eliminated all subvention payments to participating counties. Thus, it is each county's individual decision to continue the Act or begin a nine-year phase out.

According to the San Luis Obispo County Department of Agriculture, the implication of participating in the Act is a direct county loss of 3 million dollars. Historically, the county would receive around one million dollars annually in subvention payments as reimbursement for participating in the Act. In the 2008-2009 fiscal year, San Luis Obispo received $\$ 980,088$ from the State, but has not collected a subvention payment since. The San Luis Obispo County Assessor's office determined the average tax reduction was $\$ 2,370$ per contract in 2008 . Currently, the county is absorbing the tax revenue loss and has not budgeted to receive subventions since the 2008-09 budget (Hoag, 2011).

On June 7, 2011, the San Luis Obispo Board of Supervisors received recommendations from the County Agricultural Preserve Review Committee (APRC) and the Agricultural Liaison Advisor Board (ALAB) on the future of the Williamson Act in the county. Together, the committees developed five options and then delivered their recommendations separately. The first option was to keep the program "as is" and continue accepting new applications. Option two was to freeze the program. Under this option, the county would honor all existing contracts but would not enter into any new contracts. The third option was to modify the program by raising the eligibility of the 
participants, focusing on land that is more productive. Option four was to withdraw from the program and initiate the non-renewal process for all contracts. The final option was to implement the new legislation, which would replace subvention payment funding if passed. Both committees supported option one; maintaining the status quo and accepting new contract applications. Additionally, they did not support option four and considered options two and three as potential solutions if needed.

The San Luis Obispo Board of Supervisors intends to use the results of this study to guide their policy decision regarding the Williamson Act. This thesis will provide the San Luis Obispo Board of Supervisors with the necessary information to make a decision that will generate the greatest economic benefit to the County. 


\section{CHAPTER II}

\section{LITERATURE REVIEW}

Since the Williamson Act's creation in 1965, it has been evaluated from a variety of perspectives. Although there are numerous studies on the Williamson Act, a conclusive study on the overall economic benefits of the Act does not exist.

The first section of this chapter discusses the framework of the Williamson Act and its intended purposes. The second section illustrates land conversion in California and San Luis Obispo County and the factors that determine the rate and extent of urbanization. The third section offers a synthesis of historical evaluations and criticisms of the Williamson Act and its ability to preserve land. The final section includes a review of the methods used to determine the economic value of the agriculture industry.

\section{Understanding the Williamson Act}

The intent of the Williamson Act is in the California Government Code 51220. First, the Act was to preserve the limited resources available to the agriculture industry and assure an adequate and nutritious food source. Second, the Act would support agriculture's labor forces by providing adequate housing and salaries. Third, it was in the public's best interest to prevent the unnecessary and impulsive conversion of agriculture land to urban uses. Lastly, preserving open space or scenic land brings value to the state during a time of rapid urbanization (California Department of Conservation, 2010). 
Since 1965, the Act has evolved to reflect economic and political conditions (Appendix A). The most significant changes occurred in 1966 with the adoption of Article 28 (now a part of Article 13), in 1971 with the implementation of the Open Space Subvention Act, and in 1978 with Proposition 13 (Williamson Act Program: Basic Contract Provisions, 2007). Currently, the act is comprised of three interconnected statutes (Diaz and Detwiler, 2010):

- The California Land Conservation Act of 1965 (Williamson Act)

- Mandatory property tax reassessments

- Open space subventions

In return for giving up the right to develop their land, property owners enroll their farmland under the Williamson Act to receive tax benefits. The county assessor's office calculates the tax rate for land enrolled in the Williamson Act by dividing the income generated from the property by a "capitalization" rate and multiplying that value by a tax rate. The "capitalization" rate is based on the current property taxes, interest rate, and risk factors, as defined in Section 423 of the Revenue and Taxation Code. For example, a property generating an annual income of $\$ 20$ per acre with a capitalization rate of .0775 would possess an assessed value of $\$ 258$. The assessed value of $\$ 258$ would be multiplied by the tax rate of .011 , and the property taxes would be $\$ 2.84$ per acre. This calculation is highly dependent on income levels, risk factors, tax rates and interest rates, causing it to fluctuate from year to year (California Farm Bureau Federation, 1997). Overall, landowners enrolled in the Williamson Act save 20 to 75 percent in property taxes per year (California Department of Conservation, 2012). 
After passing of the Open Space Subvention Act of 1971, the State General Fund reimbursed the property tax revenues counties lost. These subvention payments were higher for prime agricultural land than for non-prime agricultural land. School districts also received indirect subvention payments to make up for the revenues lost from reduced property taxes.

The voluntary contract between the landowner and county automatically renews every year to ensure the termination date is always 9 years away. Landowners have the opportunity to sign a 20 year (18 years after the 10 percent reduction) agreement under the Farmland Security Zone program (FSZ) within the Williamson Act to receive an even lower property tax assessment. Under this program, property taxes are assessed at 65 percent of its Williamson Act valuation. The FSZ program was created in 1998 and is only available to prime farmland, farmland of statewide importance, unique farmland, and farmland of local importance (definitions found in Appendix B). As of January 1, 2009, 863,539 acres from 25 counties were enrolled under the FSZ, constituting about 6 percent of Williamson Act enrollment. In 2009, 774 acres were enrolled in the FSZ in San Luis Obispo County. Agriculture preserves must be at least 100 acres in size but two or more landowners with contiguous parcels can request to enter a contract together (Schwarzenegger, Snow, and Luther, 2010). According to the legislative oversight hearing completed in 2010, there are five ways a Williamson Act or FSZ contract may be discontinued (Diaz and Detwiler, 2010).

1. Nonrenewal: Contracts run out over the next nine years

2. Cancellation: Contracts can end immediately if counties make findings and landowners pay penalties. 
3. Recession: Contracts end when other programs protect the land.

4. Public Acquisition: Contracts end when agencies buy or condemn the land.

5. Annexation: Contracts may end when certain cities annex the land.

If a contract is discontinued through cancellation, the landowners are responsible for reimbursing the county for the tax breaks they received (Diaz and Detwiler, 2010). Because of the strict regulations and penalties involved with cancelling a contract, only seven acres in California were cancelled from the Williamson Act from 2007 to 2008 (California Department of Conservation, 2010).

The design and administration of the Williamson Act is one of its major weaknesses. Dresslar (1979) argued the Act's decentralized organization makes the execution entirely ineffective. Due to the lack of guidance and direction, the act cannot achieve effective land conservation. The primary reason for this failure is that there is no single overarching purpose to conserve land. Instead, these (sometimes conflicting) reasons exist and are combined into one issue: land conservation (Dresslar, 1979). The Williamson Act is a perfect example of a conservation policy lacking a single objective. The goals of the Williamson Act range from assuring an adequate food source, to supporting agricultural labor forces, to preserving wildlife habitat. An effective land conservation policy is essentially unattainable, because the evaluation of efficiency—land conversion, agriculture output, and environmental preservation—cannot be measured (Dresslar, 1979). 


\section{$\underline{\text { Land Conversion in California }}$}

A number of factors contribute to conversion of land, but the underlying theoretical explanation is land will be converted to the use that generates the greatest economic return (Libby and Abdalla, 2001). Thus, land that generates the smallest return (fallow land) would be urbanized first. However, land with the lowest value per acre is often non-prime land and located farther away from the urban fringe. Thus, non-prime farmland may have the greatest desire to develop, but it also has the least likelihood to be developed (Osherenko et al., 2006).

Conversely, prime farmland possesses the greatest combination of physical and chemical features for agriculture and is commonly located near cities because it is also ideal for development(Department of Conservation, 2007). Commodities grown on prime farmland have a greater value per acre, therefore, a smaller incentive to develop. However, because prime farmland has ideal qualities for development, it has greater pressure to do so.

\section{$\underline{\text { Land Conversion in San Luis Obispo County }}$}

Table 1 illustrates land conversion in San Luis Obispo County from 2006 to 2008. Only 5 percent of the land converted to urban or other uses was either prime, land of statewide importance, or unique farmland. This means 95 percent of the land converted to urban uses was grazing farmland or land of local importance (non-prime land). Roughly, 89 percent of land enrolled in the Williamson Act in San Luis Obispo County is nonprime land. In San Luis Obispo County, only 22 percent of prime land and more than 60 
percent of non-prime farmland is currently enrolled in the Williamson $\mathrm{Act}^{2}$ (Refer to Table 2).

Table 1: Land Use Conversion in San Luis Obispo County from 2006-2008 (Acres)

\begin{tabular}{|lr|r|r|r|}
\hline \multicolumn{1}{|c|}{ Land Use Category } & & $\begin{array}{c}\text { Urban and } \\
\text { Built Up } \\
\text { Land }\end{array}$ & $\begin{array}{r}\text { Total } \\
\text { Other } \\
\text { Land }\end{array}$ & $\begin{array}{c}\text { Tonvert to } \\
\text { Urban or } \\
\text { Other }\end{array}$ \\
\hline Prime Farmland & to: & 4 & 62 & 66 \\
Farmland of Statewide Importance & to: & 0 & 44 & 44 \\
Unique Farmland & to: & 0 & 76 & 76 \\
Farmland of Local Importance & to: & 121 & 1,021 & 1,142 \\
Grazing Land & to: & 144 & 1,912 & 2,056 \\
AGRICULTURAL LAND & 269 & 3,115 & 3,384 \\
SUBTOTAL & to: & -- & 34 & 34 \\
\hline Urban and Built-up Land & to: & 477 & -- & 477 \\
Other Land & to: & 1 & 0 & 1 \\
Water Area & to: & 747 & 3,149 & 3,896 \\
\hline TOTAL ACREAGE & & & \\
CONVERTED &
\end{tabular}

Source: California Farmland Conversion Summary, California Department of Conservation

Table 2: Williamson Act Enrollment by Prime and Non-Prime Land

\begin{tabular}{|c|c|c|}
\hline \multicolumn{3}{|c|}{ San Luis Obispo County } \\
Williamson Act Enrollment (Acres) \\
\hline Prime & Non-Prime & Total \\
\hline 89,501 & 700,748 & 791,023 \\
\hline
\end{tabular}

Source: 2010 Williamson Act Status Report

Tables 1 and 2 demonstrate two conditions: (1) the conversion of prime farmland, which has the highest value per acre, to urban development has been minimal in San Luis

\footnotetext{
2 This value was derived by dividing the acres of prime land enrolled in the Williamson Act from the 2009 Status Report by the total acres of prime farmland in San Luis Obispo County from the California Department of Conservation (Same method was used to determine non-prime land).
} 
Obispo County; (2) land with the lowest value per acre and the least pressure to develop comprises almost ninety percent of total Williamson Act enrollment in the County.

\section{Criticism of the Williamson Act}

The next segment of this report will evaluate the Act's ability to conserve land. Although preferential tax incentives are a popular method of land conservation, the Williamson Act has attracted an array of scholarly criticism. Even California's own assessments highlight the Act's shortcomings.

Dean (1975) established the most commonly expressed criticism. He argued prime farmland possessed the smallest comparative tax advantage under the Act since the tax assessment is based on the use-value of the land. Due to this inadequacy, land with a higher value per acre receives a smaller tax advantage compared to land with a lesser value per acre. This gives high-valued farms, which are often under the most pressure to develop and the closest to the urban fringe, even less incentive to enter into a Williamson Act contract. Farms with a high use-value often have a high market value as well, due to their proximity to urban areas and desirable qualities for development (Dean, 1975). Dean's observation is commonly agreed upon as one of the most significant failures in the Act's effectiveness.

A study by Carter et al. (1989) provided the most comprehensive evaluation of the Act. Despite being more than two decades old, this study is one of the most referenced pieces in land conservation policy. Although this report analyzes many aspects of the Williamson Act, it focuses primarily on subvention payments. These are payments to participating counties from the state government as partial reimbursement for lost 
property tax revenue. Although the values determined in the study are outdated, they effectively reflect the inadequacies of the Williamson Act subvention payments. Carter et al. (1989) estimated that in 1988-89 California experienced total property tax loss of \$120.4 million, and only \$14.5 million was reimbursed through subvention payments. This discrepancy in payments supported the authors' primary criticism that the formula used to determine subvention payments did not accurately reflect participating counties' lost revenue. They reiterated Dean's (1975) conclusion that owners of non-prime land were the greatest beneficiaries of the Act. Further, non-prime land earned the highest savings, but often contributed the least farm receipts to the local economy (Carter et al., 1989).

Carter et al. (1989) used survey data to identify the deciding factors for enrollment and dependency on tax savings. The majority of landowners stated that tax savings were not the dominant factor for enrollment, but rather, nostalgic factors had more of an influence. Nevertheless, 30 percent of respondents said they would probably sell their land without the tax savings. Responses varied significantly by county and commodity type. Again, the results supported Dean's conclusions that owners of grazing and dry-land parcels were more likely to maintain their contracts in the future than owners of row crops, vineyards, and orchard parcels (Carter et al., 1989).

In 2004, the Legislative Analyst's Office (LAO) was responsible for reviewing the effectiveness of the Act and preparing potential modifications to alleviate some of the State's budgetary obligations. The LAO had two main concerns regarding the effectiveness of the Act. First, the state has no ability to monitor the land enrolled. Specifically, the state government has no means of determining the actual level of 
pressure, if any, placed on the landowners to develop. Because of this, the Act protects more land than it needs to because property owners will pursue tax breaks even if they are not under pressure to convert. The second concern is the Act's long-term effectiveness. Assuming certain properties were under pressure to develop, the owner would likely cancel or not renew the contract. A survey of landowners from the Central Coast revealed the possible development potential of their land in the future as their sole reason for not entering into a contract (Osherenko et al., 2006). Therefore, the Act simply impedes, rather than prevents the development of land (Legislative Analyst Office, 2004).

In later studies, the effectiveness of the Act was evaluated using graphical methods. Most of these studies examine a specific location over a period of time to determine the rate of urbanization. Onested's (2007) model evaluated the effectiveness of the Act by tracking parcels' entry and exit from the act in areas experiencing urban development. This evaluation identified the Act's ability to prevent long-term urbanization. A cellular automata (SLEUTH) model was used to evaluate development by comparing land use to land changes across three factors: space, time, and human decision-making. Onested found termination of contracts to be non-random; meaning areas with the greatest pressure to develop had the most non-renewal contracts. The same factors that drive urbanization also motivate landowners to enter into non-renewal contracts. Using the SLEUTH model, Onested concluded the current application of the Williamson Act allows continual loss of farmland: however, he also determined elimination of the act would result in even greater urbanization (Onested, 2007)

Kovacs (2009) used a differential assessment program to estimate the rate in which farmland conversion would occur. He estimated duration models to evaluate rapid 
conversion of farmland in fifty-three counties in California. Data on the number of nonrenewal contracts was used to determine how quantifiable characteristics of counties influenced the rate of farmland conversion. Kovacs' results suggested proximity to major highways and income were principal determinants to rapid conversion. Additionally, appreciated agriculture land values, high agriculture commodity prices, and increased property taxes delay rapid conversion (Kovacs, 2009). These results are especially significant for this study because San Luis Obispo County's agriculture consists of both high-and low-valued commodities.

\section{Urbanization's Impact on Agriculture}

Although some doubt the Act's ability to prevent urbanization in the long term, it is commonly agreed urbanization rates would be far higher without the Act at all. The following section discusses the agricultural economic activity lost when agriculture land is converted to non-agriculture uses.

Sokolow and Kuminoff (2000) studied the economic activity lost from urban growth using land use data from the Farmland Mapping and Monitoring Program (FMMP). They focused on two interlocking themes: land use change from urban development and the economic health of the affected agriculture industry. Sokolow and Kuminoff (2000) thoroughly outlined the agriculture industry in the Sacramento Region, delineating farmland use and its value to the local economy. Next, they categorized total land in the Sacramento region by prime-land, important farmland, grazing land, urban land, other land, water, and not inventoried. The 1998 market value of each commodity produced in the region was used to find the estimated market value per acre of farmland. 
The FMMP was used to determine conversion patterns and urbanization over a ten-year period. Using the land lost to development and the market value per acre, Sokolow and Kuminoff (2000) determined the economic activity lost from land conversion in the Sacramento Region. They suggested that in the short-term, small quantities of grazing and cropland would be urbanized, and agriculture would continue to be a large part of the region's economy. Over the long run, the effects of urbanization are much more significant. Using population projections from the California Department of Finance, by 2040 the population of the Sacramento region will reach 1.6 million people requiring the conversion of 122,000 agricultural acres, reducing the region's farmland by 12 percent. Using these estimations, Sokolow and Kuminoff (2000) projected the effects of these fluctuations on the region's economy. The methodology used in this study possessed many weaknesses, because it is difficult to isolate the factors that contribute to productivity and value of agriculture. Therefore, Sokolow and Kuminoff (2000) concluded the effects of urbanization depend more on the location of development. Some producers have the ability to move production elsewhere, change commodities, or use more intensive practices, thus having little effect on agriculture's total productivity or value.

Barnard and Lucier (1998) analyzed the relationship between population growth and domestic vegetable and melon production in the top 100 vegetable producing counties in the United States. Using vegetable acreage in these counties from the Census of Agriculture from 1959 to 1992 and historical census data, the authors evaluated the impact of urban sprawl on vegetable acreage. California is a major component of the study because it makes up 53 percent of all United States' vegetable and melon 
production. California's level terrain, available water for irrigation and extended periods of warm weather make it an ideal location for vegetable and melon production, but these characteristics are also highly valued for urban development. Barnard and Lucier (1998) concluded urbanization does not appear to pose immediate threats to the U.S production of vegetables and melons. They even hypothesized urbanization and vegetable production possesses a positive relationship. Due to vegetables' high production intensity/high net return characteristic, production of vegetables is perhaps one the least affected by urbanization when compared to other agricultural commodities (Barnard and Lucier, 1998). This conclusion echoes Sokolow and Kuminoff's (2000) prediction that, in some situations, urbanization does not necessarily reduce agriculture production or value. Instead, landowners adopt more intensive practices or convert their operation to commodities that produce higher yields per acre, like vegetables (Sokolow and Kuminoff, 2000).

\section{Valuing Agriculture Using IMPLAN}

Numerous studies have evaluated the economic impact of agriculture in California. The most comprehensive study is "The Measure of California Agriculture" from The University of California Agriculture Issues Center (2009). The multiplier effect was used to determine the agriculture industry's effect on workforce, labor income, and value added to an economy. Every dollar generated within the agriculture industry stimulates additional economic activity through labor income, employment and value added. Using data from the U.S. Bureau of Economic Analysis, the study determined agriculture and related industries accounted for 1.45 percent of California' Gross State Product (GSP) in 2003. By using direct, indirect and induced effects, the study found 
agricultural production and processing accounted for 7.3 percent of the private workforce, 6.5 percent of the state's value added, and 5.6 percent of labor income. This report also conducted analysis of the agriculture industry on a regional basis. An analysis of the Central Coast ${ }^{3}$ suggested the agriculture industry accounted for 3.5 percent of the regional labor income and 4 percent of the regional value added (UC Agriculture Issues Center, 2009).

Additional studies have been done focusing on specific regions or crops, and often identify disaggregated impacts. McClusky and Goldman (1995) focused on the impacts of the agriculture industry in Ventura County. This study is particularly interesting for this report because Ventura County produces similar commodities to San Luis Obispo County. Fruit and nut crops and vegetable crops are the two top grossing commodities in both counties (San Luis Obispo Department of Agriculture, 2010). McClusky and Goldman found agriculture and related industries accounted for 8 percent of county's employment, 8.09 percent of the county's personal income, and 7.22 percent of the county's value added. Because Ventura County is a large producer of high-value and labor-intensive commodities, the agriculture industry is a larger contributor to the local economy than at the state level (McClusky and Goldman, 1995).

Hamilton (2004) conducted a comprehensive study showing the economic impact of specialty crops on the top five counties that produce specialty crops in California; Monterey, Fresno, Kern, Tulare, and San Diego Counties. Hamilton (2004) determined the percent of total income, value added, and total jobs the specialty crop industry

\footnotetext{
${ }^{3}$ The Central Coast was defined as Alameda, Contra Costa, Monterey, San Benito, Santa Clara, Santa Cruz, San Luis Obispo and San Mateo counties.
} 
accounted for in each county. The results showed great variation depending on the county. Monterey County indicated the greatest impact from the production of specialty crops accounting for 11.5 percent of total income, 12.2 percent of total value added, and 16.2 percent of jobs. The production of specialty crops had the smallest impact on San Diego County's economy, accounting for 0.7 percent of total income, 1.1 percent of total value added, and 1.2 percent of jobs. Hamilton's (2004) study suggested the agricultural industry's economic impacts could vary widely, depending on the size or diversity of an economy. The aforementioned studies share a common conclusion: commodities that are labor intensive and high valued have a larger impact on an economy. This is important because 89 percent of San Luis Obispo County's total agriculture receipts were from high-valued, specialty crops ${ }^{4}$ (San Luis Obispo Department of Agriculture, 2010).

\footnotetext{
${ }^{4}$ Specialty crops are identified as fruit and nut crops, vegetable crops and nursery products.
} 


\section{CHAPTER III}

\section{METHODOLOGY}

\section{$\underline{\text { Procedures for Data Collection }}$}

Disaggregating the San Luis Obispo County data into zip codes and then aggregating the zip codes into sub-county regions was an essential step in this study. As Williamson Act enrollment is concentrated in specific parts of the county, cancellations of the Act will have a larger economic impact on those regions with greater enrollment. In addition, the geographic difference in agriculture production across the county influences the potential economic changes that might ensue if the Act was cancelled. Analyzing isolated regions provides a more accurate reflection of the potential changes to the local economy.

\section{Williamson Act Data}

The San Luis Obispo County Assessor's office provided current enrollment in the Williamson Act by Assessor Parcel Numbers (APN) and listed the total acreage of each parcel enrolled. To isolate Williamson Act enrollment by zip code, the parcel data was loaded into ArcView, a Geographic Information Systems (GIS) mapping program. First, a map of total Williamson Act enrollment in the county was compiled. Then, a map of the zip codes in San Luis Obispo County was created and layered on top of the enrollment data. This map provides a visual of the differences in enrollment throughout the county and identifies total enrollment by acres in each zip code (See Figure 1). 


\section{Input-Output Modeling and Economic Data}

IMPLAN (IMpact Analysis for PLANning), a program developed by the U.S. Forest Service to estimate economic input-output models, was used in this study. An input-output model quantifies the interdependencies between industries in an economy. The IMPLAN model applies the economic theories of Wassily Leontief, one of the original economists to focus on input-output analysis in an economy. Leontief developed an input-output model in matrix form to show inter-industry relations within an economy. The Leontief matrix illustrates how inputs produced by one industry are used to produce an output in another industry that are then either consumed or used as an input by an additional industry. The matrix identifies how dependent each industry is on other sectors of the economy. As one industry changes its consumption or output the matrix measures the effects before and after the changes occur (Landefeld and McCulla, 1999). IMPLAN uses the input-output matrix theory to show the multiplier effect of an industry throughout an economy.

IMPLAN divides the economy into 528 sectors, and estimates the multiplier effect of an industry using direct, indirect and induced effects. These effects are measured as a dollar value and are used to quantify the value of output, labor income, jobs, and value added before and after changes occur in an industry. Direct effects measure the immediate output of an industry and are determined by the inputs that an industry uses. Indirect effects are secondary effects one industry has on another industry due to the relationships between one another. Induced effects are caused by changes in household 
consumption of goods and services measured in income, value added and employment (University of California Agricultural Issues Center, 2009). The IMPLAN database is compiled annually from the U.S. Census Bureau, the Bureau of Labor Statistics, the U.S. Department of Agriculture, among other federal data gathering agencies. IMPLAN data is available at the national, state, county or zip code level. The program incorporates local economic data so that any changes in a local industry can be evaluated based on the current economic conditions. The most recent data set available is 2010 .

The data set for San Luis Obispo County is divided by zip code to differentiate between the diverse commodities produced within the county. The zip code data provided by IMPLAN was based on the 2007 Census of Agriculture. However, the Census of Agriculture does not collect all data at the zip code level, so IMPLAN researchers estimate zip code level agriculture production data by using weighted averages from the county level data. An initial examination of zip code level data revealed obvious inaccuracies in the distribution and variety of agriculture production in San Luis Obispo County. IMPLAN notes in its data information that for the agriculture industry, zip code level data may be inaccurate because of the estimation errors, and advises IMPLAN users to update and correct the data set using local data if possible. More accurate output values were determined using the 2007 Agriculture Census and the 2010 San Luis Obispo County Crop Report. The 2007 Agriculture Census provided the number of operations in each zip code for the following industries: Cattle ranching, vegetable production, fruit and tree nut production, greenhouse and horticulture production, grain farming, and other field crops. By dividing the number of operations in a zip code by the total number of operations in the county, a more accurate estimate of agriculture activity for that 
commodity was determined (ex: zip code 93446 has 91 cattle operations out of 614 in the county, so $15 \%$ of cattle operations are in 93446). Next, the total output value for each commodity group from the 2010 San Luis Obispo County Crop Report was multiplied by the percent of total operations in each county (ex: 15\% of cattle operations are in zip code 93446 and the county's total output value for cattle is $\$ 53,374,000$, thus 93446 's total cattle output is $\$ 8,751,413)$. This generated a more accurate output value for each commodity at the zip code level. San Luis Obispo County agricultural industry experts verified the data estimations for each zip code. These output levels were entered into IMPLAN to strengthen the accuracy of each zip code model.

\section{$\underline{\text { Procedures for Data Analysis }}$}

An IMPLAN analysis was run on five models in this study. There are twenty active zip codes in the county. One model analyzed the entire county, and the remaining four models were a compilation of zip codes representing a different region of the county. These four areas were established based on Williamson Act enrollment and similarities in agricultural production among the zip codes.

The first model analyzed represents the entire county and includes all twenty zip codes. It assesses the contribution of the agricultural industry in San Luis Obispo County as a whole. Due to the diverse nature of the agriculture industry in the county, four additional models were constructed: North Coast, North East, South Coast, and South East (See Table 8). The preliminary output values for each zip code and commodity were allocated into these four models and input into IMPLAN. After updating the total output value for each commodity, the Value Added values were manually adjusted to match the 
new output value, as IMPLAN does not automatically adjust for changes made to its production values database. Total Value Added is made up of four components: Employee Compensation, Proprietor Income, Other Property Type Income, and Indirect Business Tax. Each value added component is a percent of the output value, but these vary by industry, according to the multipliers developed by IMPLAN. The following table illustrates Value Added for each commodity.

Table 3: IMPLAN Multipliers by Commodity

\begin{tabular}{l|r|r|r|r|r|r}
\hline IMPLAN Multiplier & \multicolumn{1}{c|}{ Cattle } & Vegetables & \multicolumn{1}{c|}{ Fruit } & Greenhouse & Grain & Other \\
\hline $\begin{array}{l}\text { Employee } \\
\text { Compensation }\end{array}$ & $2.15 \%$ & $3.33 \%$ & $3.87 \%$ & $7.52 \%$ & $0.93 \%$ & $2.61 \%$ \\
$\begin{array}{l}\text { Proprietor Income } \\
\begin{array}{l}\text { Other Property Type } \\
\text { Income }\end{array}\end{array}$ & $0.39 \%$ & $29.50 \%$ & $32.59 \%$ & $38.48 \%$ & $8.00 \%$ & $15.26 \%$ \\
& $11.99 \%$ & $17.02 \%$ & $14.46 \%$ & $19.40 \%$ & $11.53 \%$ & $9.04 \%$ \\
Indirect Business Tax & $2.08 \%$ & $1.10 \%$ & $2.26 \%$ & $0.87 \%$ & $-0.01 \%$ & $4.06 \%$ \\
\hline
\end{tabular}

Source: IMPLAN v. 3.0

The first round of analysis measured the baseline economic impact of the agriculture industry in San Luis Obispo County. Then, scenarios from the preliminary research analyzing different levels of Williamson Act contract cancellations were evaluated. Scenarios in IMPLAN shock the economy by adjusting the total output of an industry. Each region will experience two scenarios: a high and low level of contract cancellations. In order to reflect these scenarios in IMPLAN, the change in total output for each commodity needs to be determined.

The consequences of removing the Williamson Act depend on a number of factors. First, other land use restrictions, like zoning, limit the opportunity for development and preserve agriculture production. Second, the current state of the economy influences the use of land and the choice of commodities produced. Lastly, the 
percent of total expenses allocated to property taxes impacts an operation's profitability, thus, the production decisions.

There are three likely outcomes to land removed from the Williamson Act: (1) the land stays in production under existing or new ownership; (2) the land becomes fallow; (3) or the land is developed. However, a large portion of land enrolled in the Williamson Act is also zoned for agriculture. Changing the zoning of a property is done through the city or county, and varies in difficulty depending on its location. Overall, it is typically difficult and expensive to change a property's zoning. A GIS map of San Luis Obispo County parcels enrolled in the Williamson Act and zoned for agriculture identified the land vulnerable to urbanization. This map shows 99 percent of land enrolled in the Williamson Act is also zoned for agriculture. Therefore, it is reasonable to assume only a small percent of land is expected to be developed (Refer to Figure 1). 


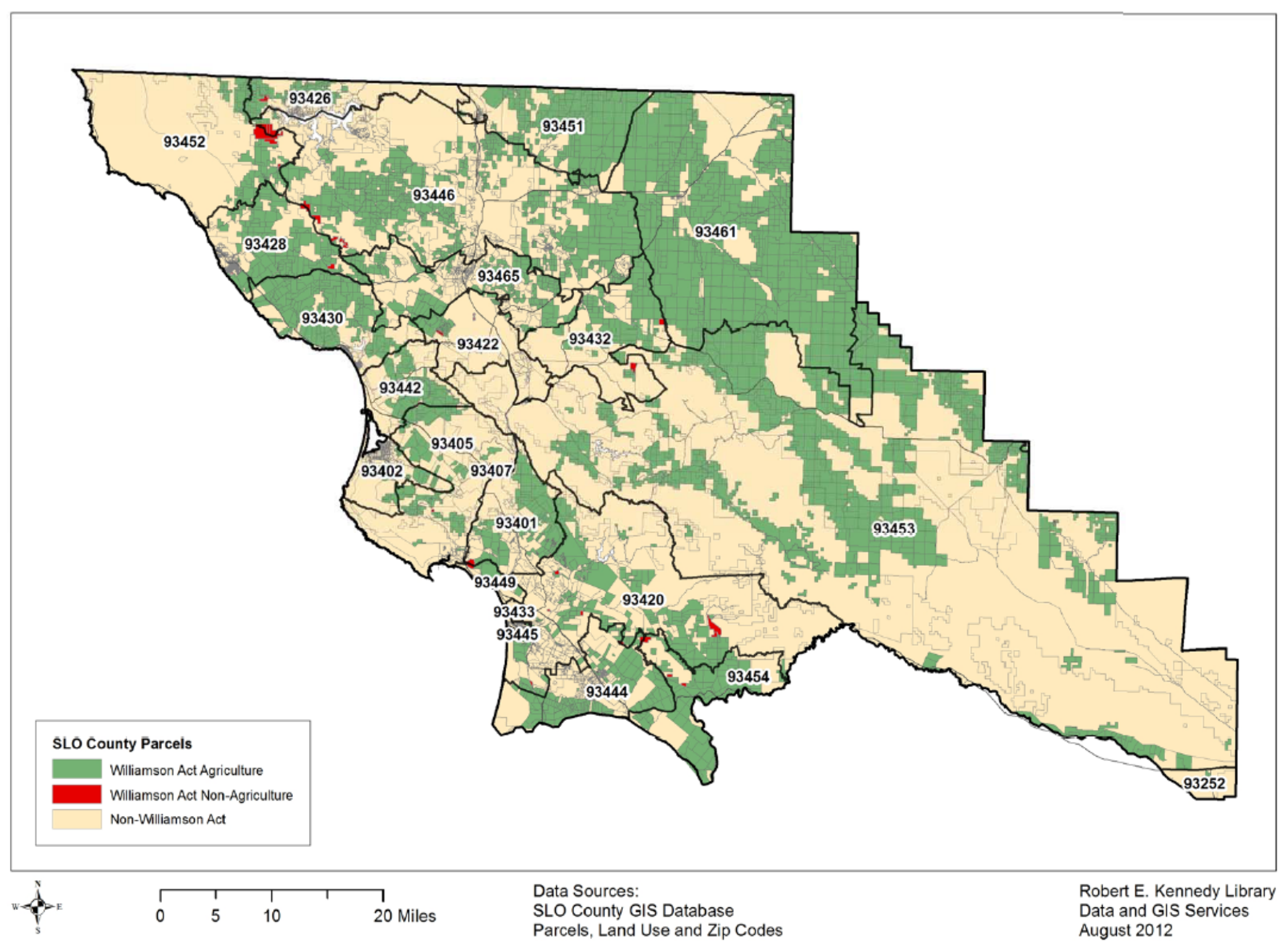

Figure 1: San Luis Obispo County Williamson Act Parcels and Zoning 
The current state of the agriculture industry in San Luis Obispo County and California has a direct effect on the anticipated changes to the economy if the Williamson Act was cancelled. In 2011, the top three commodities in San Luis Obispo were strawberries, wine grapes, and cattle. Strawberries have become a significant crop in southern San Luis Obispo County. Strawberries were the most profitable crop in the county in 2011, accounting for 24 percent of total agriculture output (San Luis Obispo County Department of Agriculture, 2011). The Central Coast continues to gain recognition as an ideal area to grow grapes, making prices consistently above the California average. Bulk wine grape prices are climbing as an anticipated shortage drives price up (Turrentine Report, 2012). Cattle are also experiencing higher than average prices, with stockers reaching $\$ 170$ per hundredweight, $\$ 30-40$ above their average price. On a global front, corn and soybean prices are at record high prices. These feed grain prices directly affect cattle prices for the area, as the value of grass-fed weight gain becomes more efficient then grain-fed weight gain in feedlots (Cattle Fax, 2012). In addition, agriculture land values have also seen a rise in price per acre. This has been attributed to an increase in crop values, as land values are typically more responsive to crop prices than protein prices. Overall, the agriculture industry is in an upturn with increasing crop prices and high land values. As Dean (1975) observed, high priced commodities will receive a smaller tax benefit, so if prices continue to rise, the land owner's tax benefit will decrease. Under these circumstances, if the Williamson Act were cancelled the difference in property taxes would be minimal for high-valued commodity land. 
It is difficult to estimate how the elimination of the Act will affect landowners and their operations because the tax benefits are dependent on the use of the land, therefore varying for each parcel. To estimate how much farmers typically budget for property taxes, UC Davis Current Cost and Return Studies were used. These studies are based on current prices at the time of the study and production practices considered typical for the area and commodity. Although the studies are based on assumptions, they are reflective of a farming operation's typical costs and returns. Cost and Return studies were analyzed for strawberries, broccoli, cow/calf operations and wine grapes because they were the top four commodities in San Luis Obispo in 2011. Five wine grape studies were used to reflect a more accurate range of property tax expenses. For strawberries, broccoli and cattle operations, property taxes account for roughly 1 percent of their total costs. Wine grape producers typically allocate between 1.5 and 8 percent of their total costs toward property taxes. This range is substantial, and reflects the range in property values among regions. The difference in vineyard property taxes among regions provides a reasonable range for San Luis Obispo County. 
Table 4: UC Davis Cost of Production Studies-Property Taxes Analysis

\begin{tabular}{|c|c|c|c|c|c|}
\hline Location & Commodity & Year & $\begin{array}{c}\text { Property } \\
\text { Tax Cost } \\
\text { (Per } \\
\text { Acre) }\end{array}$ & $\begin{array}{l}\text { Total Costs } \\
\text { (Per Acre) }\end{array}$ & $\begin{array}{l}\text { Property } \\
\text { Taxes as a } \\
\% \text { of Total } \\
\text { Costs }\end{array}$ \\
\hline Central and South Coast & Strawberries & 2011 & 14 & 41,381 & $0.03 \%$ \\
\hline San Luis Obispo County & Broccoli & 2012 & 7 & 6,069 & $0.12 \%$ \\
\hline Sonoma County & Cab. Sauv. & 2010 & 944 & 12,304 & $7.67 \%$ \\
\hline San Joaquin Valley & Cab. Sauv. & 2012 & 230 & 5,438 & $4.23 \%$ \\
\hline Lake County & Sauv. Blanc & 2008 & 359 & 7,256 & $4.95 \%$ \\
\hline Lake County & Cab. Sauv. & 2008 & 380 & 7,728 & $4.92 \%$ \\
\hline Sacramento Valley & Chardonnay & 2008 & 87 & 5,528 & $1.57 \%$ \\
\hline Location & Commodity & Year & $\begin{array}{c}\text { Property } \\
\text { Tax Cost } \\
\text { (Per 300 } \\
\text { Hd) }\end{array}$ & $\begin{array}{c}\text { Total Costs } \\
\text { (Per 300 } \\
\text { Hd) }\end{array}$ & $\begin{array}{c}\text { Property } \\
\text { Taxes as a } \\
\% \text { of Total } \\
\text { Costs }\end{array}$ \\
\hline Sacramento Valley & $\begin{array}{l}300 \mathrm{Hd}, \\
\text { Cow/Calf }\end{array}$ & 2008 & $\$ * 2,000$ & 199,902 & $1.00 \%$ \\
\hline
\end{tabular}

*Cow Calf Operation Study value represents insurance and tax expense

Source: UC Davis Cooperative Extension Current Cost and Return Studies

The UC Davis cost studies provide the estimated costs of property taxes for the specified operation. The important question, however, is to determine how changes in these costs will affect an operation's output. According to microeconomic theory, a profitmaximizing firm will produce at a level where marginal revenue is equal to marginal cost. An increase in property taxes would raise the fixed costs associated with the operation. Marginal cost represents the cost of producing an additional unit, and is calculated by dividing the change in total cost by the change in quantity. An increase in fixed costs does not affect marginal cost, thus, having no effect on the profit maximizing output or price. Therefore, an increase in property taxes would have little to no effect on 
the output of an operation. In fact, one could argue that there is incentive to increase productivity per acre, to reduce the average fixed cost of production per acre.

Additionally, assumptions can be made based on the commodity being produced. As discussed earlier, low-valued commodities receive the greatest tax benefit and highvalued commodities receive the lowest. Therefore, farms that produce high-valued crops are less financially dependent on the tax benefit and less likely to decrease or go out of production without the Williamson Act. Conversely, producers of low-valued commodities will suffer greater financial distress without the tax benefits. Due to this element of preferential tax incentives, it is reasonable to assume changes in production will be relatively the same for a commodity regardless of where it is produced in the county.

In San Luis Obispo, zoning restrictions limit the opportunity for development, thus, it is reasonable to predict land will either stay in production or go fallow if the Williamson Act is removed. Due to the relatively low impact of property taxes on cost of production, and the recent high commodity prices, removing the Act will have a minimal effect an operation's profitability. Additionally, microeconomic theory proves an increase in property taxes, a fixed cost of production, will not affect the profit-maximizing output. Therefore, conservative estimations of the anticipated changes in output were made based on commodity type (refer to Table 5). For high-valued crops-Fruit and $\mathrm{Nut}^{5}$, Vegetables, and Horticulture-output is estimated to decrease by 1 percent in the low scenario and 3 percent in the high scenario. Relatively lower-valued commodities-

\footnotetext{
${ }^{5}$ Fruit and Nut production is aggregated together by the USDA. There is little nut production in San Luis Obispo County.
} 
cattle, grains, and other commodities - output is predicted to decrease by 3 percent in the low circumstance and 5 percent in the high scenario. Using these estimates, this study will determine the change to direct sales, total sales, total income, total value added and number of jobs lost due to a reduction in output as a result in Williamson Act contract cancellations.

Table 5: IMPLAN Adjustments to Output by Commodity

\begin{tabular}{|c|c|c|}
\hline \multirow[b]{2}{*}{ Commodity } & \multicolumn{2}{|c|}{ Scenario } \\
\hline & $\begin{array}{c}\text { High } \\
(\% \text { Loss in Output })\end{array}$ & $\begin{array}{c}\text { Low } \\
(\% \text { Loss in Output) }\end{array}$ \\
\hline Vegetables & $-3 \%$ & $-1 \%$ \\
\hline Fruit and Tree Nut & $-3 \%$ & $-1 \%$ \\
\hline Nursery/Horticulture & $-3 \%$ & $-1 \%$ \\
\hline Cattle & $-5 \%$ & $-3 \%$ \\
\hline Grain & $-5 \%$ & $-3 \%$ \\
\hline Other Field Crops & $-5 \%$ & $-3 \%$ \\
\hline
\end{tabular}




\section{CHAPTER IV}

\section{RESULTS}

Before implementing economic shocks to the models in IMPLAN, it is important to evaluate the overall economic value of the agriculture industry in San Luis Obispo County. Agriculture creates substantial ripple effects in an economy, because of its interrelationships among industries. Table 6 highlights employment, total output, labor income and total value added for the agriculture industry in San Luis Obispo County for 2010. The industries chosen for this model were based on the 2010 Crop Report for San Luis Obispo County. The total output levels for Animals, Field Crops, Nursery Production, Fruit and Nut, and Vegetable production from the Crop Report were input into IMPLAN to strengthen the accuracy of the model. Additional industries like Wineries and Support Activities for Agriculture were also included to show a more accurate reflection of the agriculture industry in the County. Although wineries are not a direct agriculture commodity, it is reasonable to assume the majority of the grapes used in the production of wine were grown in San Luis Obispo County. It would be inappropriate to exclude wineries from the valuation of the agriculture industry in San Luis Obispo because they make up a large portion of the local agriculture economy.

Support activities for agriculture account for the greatest area of agricultural employment in the County. Examples of support activities are seed producers, pesticide distributers, farm and ranch managers, vineyard consulting, excavation, and packaging facilities. Although wineries possess the largest output value, fruit farming contributes 
the greatest total value added to the County. This is due to the intensive production process of grapes and strawberries, the two prominent fruit varieties grown in the County. Additionally, labor income from fruit production accounts for the largest portion of total labor income because of the demanding harvesting process.

Table 6: Summary Analysis of Agriculture in San Luis Obispo County

\begin{tabular}{|c|c|c|c|c|}
\hline Industry & $\begin{array}{l}\text { Employ- } \\
\text { ment (\# } \\
\text { of Jobs) }\end{array}$ & Output & Labor Income & Value Added \\
\hline Oilseed farming & 1.3 & $\$ 192,249$ & $\$ 23,342$ & $\$ 79,682$ \\
\hline Grain farming & 25.2 & $2,809,000$ & 250,996 & 574,654 \\
\hline Vegetable and melon & 447.6 & $176,666,000$ & $58,001,141$ & $90,021,103$ \\
\hline Fruit farming & $1,301.3$ & $365,750,031$ & $133,360,887$ & $194,505,405$ \\
\hline $\begin{array}{l}\text { Greenhouse, nursery, and } \\
\text { floriculture }\end{array}$ & 296.8 & $94,708,000$ & $43,566,152$ & $62,761,707$ \\
\hline All other crop farming & 37.8 & $6,511,000$ & $1,163,169$ & $2,015,964$ \\
\hline Cattle ranching & 158.6 & $53,374,001$ & $1,354,779$ & $8,867,051$ \\
\hline $\begin{array}{l}\text { Animal production, } \\
\text { except cattle, poultry, } \\
\text { eggs }\end{array}$ & 56.7 & $5,983,276$ & 413,951 & $2,928,475$ \\
\hline $\begin{array}{l}\text { Support activities for } \\
\text { agriculture and forestry }\end{array}$ & $3,158.4$ & $108,204,407$ & $81,641,370$ & $79,634,116$ \\
\hline Wineries & $1,197.7$ & $505,753,265$ & $64,843,277$ & $132,376,341$ \\
\hline $\begin{array}{l}\text { Total } \\
\text { Source: IMPLAN v. } 3.0\end{array}$ & $6,681.4$ & $\$ 1,319,951,229$ & \$ 384,619,064 & $\$ 553,764,498$ \\
\hline
\end{tabular}

Table 7 illustrates the direct, indirect and induced effects for each commodity. The industry multipliers are derived from these values. They represent the relationship between total effects and direct effects for the given industry. Direct effects represent the expenditures applied to the predictive model. It is the change in production or spending by producers or consumers, due to a policy or activity. Indirect effects represent the 
impact of local industries purchasing services and goods from other local industries.

Induced effects are the response to initial change due to the re-spending of income earned by a component of value added. Multipliers vary among commodities depending on the production of the commodity and its relationship to input processing businesses located within the region. Cattle ranching possesses the greatest multiplier, with 1.84. All other Crop Farming and Fruit Farming have the second and third most significant multiplier with 1.75 and 1.73, respectively. Cattle ranching and other Crop Farming have large indirect effects on the economy. These industries are highly interrelated to other industries and heavily rely on other producers of goods and services. Conversely, fruit farming and floriculture possesses larger induced effects on the economy.

Table 7: Total Effects of Agriculture in San Luis Obispo County

\begin{tabular}{lcccc}
\hline Industry & $\begin{array}{c}\text { Direct } \\
\text { Effects }\end{array}$ & $\begin{array}{c}\text { Indirect } \\
\text { Effects }\end{array}$ & $\begin{array}{c}\text { Induced } \\
\text { Effects }\end{array}$ & $\begin{array}{c}\text { Total Multiplier } \\
\text { Effects }\end{array}$ \\
\hline Oilseed farming & 1.00 & 0.37 & 0.15 & 1.51 \\
Grain farming & 1.00 & 0.54 & 0.16 & 1.70 \\
Vegetable and melon & 1.00 & 0.37 & 0.31 & 1.69 \\
Fruit farming & 1.00 & 0.37 & 0.35 & 1.73 \\
$\begin{array}{l}\text { Greenhouse, nursery, and } \\
\text { floriculture }\end{array}$ & 1.00 & 0.29 & 0.38 & 1.67 \\
All other crop farming & 1.00 & 0.52 & 0.23 & 1.75 \\
Cattle ranching & 1.00 & 0.75 & 0.09 & 1.84 \\
$\begin{array}{l}\text { Animal production, except } \\
\text { cattle, poultry, eggs }\end{array}$ & 1.00 & 0.30 & 0.10 & 1.39 \\
$\begin{array}{l}\text { Support activities for } \\
\text { agriculture and forestry }\end{array}$ & 1.00 & 0.12 & 0.53 & 1.65 \\
Wineries & 1.00 & 0.39 & 0.17 & 1.56 \\
\hline
\end{tabular}

Source: IMPLAN v. 3.0

After determining the overall economic impact of the agriculture industry in the county, five IMPLAN models were developed and analyzed. One model was developed 
for the entire county, with four additional models representing different regions of the County. These four areas were established based on Williamson Act enrollment and similarities in agricultural production among the zip codes. Table 8 shows the zip codes included in each region. Total Williamson Act enrollment in these regions is illustrated in Table 9. Two scenarios were conducted in each model to represent the potential changes in the economy if the Williamson Act was removed. Conservative estimates were used in the analysis to represent the low and high changes to agriculture output. As discussed in Chapter 3, the output for high valued crops decreases by 1 percent in the low scenario and 3 percent in the high scenario. Output for low valued crops was anticipated to decrease by 3 percent in the low scenarios and 5 percent in the high scenario. Using these adjustments, this study estimated the change to direct sales, total sales, total income, total value added and number of jobs lost due to a reduction in output as a result of Williamson Act contract cancellations.

Table 8: Regional Models

\begin{tabular}{|c|c|c|c|c|c|c|c|}
\hline \multicolumn{2}{|c|}{ North Coast } & \multicolumn{2}{|c|}{ South Coast } & \multicolumn{2}{|c|}{ North East } & \multicolumn{2}{|c|}{ South East } \\
\hline $\begin{array}{c}\text { Zip } \\
\text { Code } \\
\end{array}$ & City & $\begin{array}{c}\text { Zip } \\
\text { Code }\end{array}$ & City & $\begin{array}{l}\text { Zip } \\
\text { Code }\end{array}$ & City & $\begin{array}{c}\text { Zip } \\
\text { Code }\end{array}$ & City \\
\hline 93452 & $\begin{array}{l}\text { San } \\
\text { Simeon }\end{array}$ & 93442 & Morro Bay & 93422 & Atascadero & 93405 & $\begin{array}{l}\text { San Luis } \\
\text { Obispo } \\
\text { San Luis }\end{array}$ \\
\hline 93428 & Cambria & 93402 & Los Osos & 93432 & Creston & 93407 & $\begin{array}{l}\text { Obispo } \\
\text { San Luis }\end{array}$ \\
\hline 93430 & Cayucos & 93444 & Nipomo & 93446 & Paso Robles & 93401 & Obispo \\
\hline & & 93449 & Pismo Beach & 93465 & Templeton & 93420 & Arroyo Grande \\
\hline & & 93445 & Oceano & 93461 & Shandon & 93453 & Santa Margarita \\
\hline & & 93433 & Grover Beach & 93451 & San Miguel & & \\
\hline
\end{tabular}


Table 9: Total Williamson Act Enrollment

\begin{tabular}{lcr}
\hline Region & \multicolumn{1}{c}{ Acres } & Total (\%) \\
\hline North Coast & 76,745 & $9.61 \%$ \\
South Coast & 45,641 & $5.72 \%$ \\
North East & 392,980 & $49.23 \%$ \\
South East & 282,908 & $35.44 \%$ \\
\hline \hline Total & 798,274 &
\end{tabular}

The results of the study are delivered in two Impact Summary tables for each model. Tables 10 through 19 show the direct, indirect, induced, and total effects to employment, labor income, total value added, and output for the economy in question. The analysis should be interpreted as an estimation of how San Luis Obispo might be affected if the Williamson Act was cancelled and agriculture output was reduced as a result.

Tables 10 and 11 illustrate the results of the first model, which represent all of San Luis Obispo and include all 20 zip codes. It is important to depict the county in one model because agriculture activities are related in multiple ways, making it difficult to separate the impacts of one industry with another in different regions. This is why the total effects in the County-wide model is not the sum of the effects of each zip code cluster (UC Agriculture Issues Center, 2009). As regions are separated in IMPLAN, some of the economic activity that would trickle into the surrounding regions is lost. This loss of economic activity is referred to as leakage. Therefore, evaluating the county as a whole shows a greater loss in economic activity than evaluating it on a sub-county basis. 
The total output lost in the high scenario is roughly $\$ 40$ million, which is about 5 percent of total agriculture output in 2010. An additional \$22 dollars is projected to be lost in value added income and \$13 million in labor income.

\section{Table 10: Impact Summary San Luis Obispo County Low Scenario}

\begin{tabular}{l|r|r|r|r}
\hline Impact Type & \multicolumn{1}{|c|}{$\begin{array}{c}\text { Employment } \\
(\text { Jobs })\end{array}$} & Labor Income (\$) & Value Added (\$) & Output (\$) \\
\hline Direct Effect & -28.30 & $-2,650,926$ & $-4,154,185$ & $-8,252,060$ \\
Indirect Effect & -38.00 & $-1,231,165$ & $-2,049,869$ & $-3,819,695$ \\
Induced Effect & -20.50 & $-782,048$ & $-1,588,206$ & $-2,564,241$ \\
\hline \hline Total Effect & -86.70 & $-4,664,140$ & $-7,792,260$ & $-14,635,996$ \\
\hline
\end{tabular}

Table 11: Impact Summary San Luis Obispo County High Scenario

\begin{tabular}{l|r|r|r|r}
\hline Impact Type & \multicolumn{1}{|c|}{$\begin{array}{c}\text { Employment } \\
\text { (Jobs) }\end{array}$} & Labor Income (\$) & Value Added (\$) & \multicolumn{1}{c}{ Output (\$) } \\
\hline Direct Effect & -75.70 & $-7,833,464$ & $-11,972,322$ & $-22,248,420$ \\
Indirect Effect & -104.20 & $-3,402,041$ & $-5,415,271$ & $-9,631,800$ \\
Induced Effect & -59.30 & $-2,262,668$ & $-4,595,523$ & $-7,419,167$ \\
\hline \hline Total Effect & -239.10 & $-13,498,174$ & $-21,983,117$ & $-39,299,387$ \\
\hline
\end{tabular}

The North Coast model includes the following zip codes: 93452, 93430 and 93428. This region has the smallest agriculture influence, with only $\$ 42$ million in output. Fruit production is the predominant commodity in this region. Due to a limited amount of agriculture activity in the North Coast, little economic change can be expected if the Williamson Act was cancelled. Additionally, the North Coast has the least number of acres enrolled in the Williamson Act, accounting for only 9 percent of total enrollment (See Table 9). 
Table 12: Impact Summary North Coast Low Scenario

\begin{tabular}{l|r|r|r|r}
\hline Impact Type & $\begin{array}{c}\text { Employment } \\
\text { (Jobs) }\end{array}$ & Labor Income (\$) & Value Added (\$) & Output (\$) \\
\hline Direct Effect & -1.4 & $-154,470$ & $-245,423$ & $-497,513$ \\
Indirect Effect & -1.1 & $-34,040$ & $-65,215$ & $-126,394$ \\
Induced Effect & -0.4 & $-12,482$ & $-34,077$ & $-50,588$ \\
\hline \hline Total Effect & -2.9 & $-200,992$ & $-344,715$ & $-674,495$ \\
\hline
\end{tabular}

Table 13: Impact Summary North Coast High Scenario

\begin{tabular}{l|r|r|r|r}
\hline Impact Type & $\begin{array}{c}\text { Employment } \\
\text { (Jobs) }\end{array}$ & Labor Income (\$) & Value Added (\$) & Output(\$) \\
\hline Direct Effect & -3.7 & $-457,982$ & $-708,123$ & $-1,339,780$ \\
Indirect Effect & -3.0 & $-94,439$ & $-168,103$ & $-298,471$ \\
Induced Effect & -1.2 & $-36,609$ & $-99,955$ & $-148,380$ \\
\hline \hline Total Effect & -7.8 & $-589,030$ & $-976,182$ & $-1,786,631$ \\
\hline
\end{tabular}

The North East region is the largest agriculture-producing region in the county. It is evident this region would sustain the largest economic impact if the Williamson Act was cancelled. The North East region accounts for nearly 50 percent of all Williamson Act enrollment. Fruit production alone accounts for $\$ 238$ million in output, roughly 68 percent of total agriculture output in this region. Because fruit is a high-valued commodity, the estimated decrease in output was minimal. However, despite these conservative estimates, sizeable economic value is lost. Shifts in output have a larger effect on value added in this region because of the large emphasis on fruit production. This region also accounts for the greatest level of cattle production in the county, with roughly $\$ 29$ million in output in 2010 . Cattle operations, a lower-value commodity, are more dependent on the tax benefits of the Williamson Act. Shifts in their fixed costs would have a greater impact on their profitability, making them more sensitive to an increase in property taxes. Roughly 19 million dollars are projected to be lost in total output and 10 million dollars in value added in this region. 
Table 14: Impact Summary North East Low Scenario

\begin{tabular}{l|r|r|r|r}
\hline Impact Type & \multicolumn{1}{|c|}{$\begin{array}{c}\text { Employment } \\
\text { (Jobs) }\end{array}$} & Labor Income (\$) & Value Added (\$) & Output (\$) \\
\hline Direct Effect & -17.4 & $-1,323,181$ & $-2,075,439$ & $-4,227,446$ \\
Indirect Effect & -21.4 & $-639,427$ & $-963,330$ & $-1,760,027$ \\
Induced Effect & -9.2 & $-361,082$ & $-718,472$ & $-1,122,937$ \\
\hline \hline Total Effect & -48.0 & $-2,323,690$ & $-3,757,240$ & $-7,110,410$ \\
\hline
\end{tabular}

Table 15: Impact Summary North East High Scenario

\begin{tabular}{l|r|r|r|r}
\hline Impact Type & \multicolumn{1}{|c|}{$\begin{array}{c}\text { Employment } \\
\text { (Jobs) }\end{array}$} & Labor Income (\$) & Value Added (\$) & Output (\$) \\
\hline Direct Effect & -46.7 & $-3,895,175$ & $-5,942,776$ & $-11,265,443$ \\
Indirect Effect & -57.8 & $-1,742,163$ & $-2,482,598$ & $-4,270,206$ \\
Induced Effect & -26.3 & $-1,036,727$ & $-2,063,154$ & $-3,224,399$ \\
\hline \hline Total Effect & -130.9 & $-6,674,065$ & $-10,488,528$ & $-18,760,048$ \\
\hline
\end{tabular}

The South Coast region accounts for roughly 20 percent of the County's agriculture output. The majority of agriculture production in the South Coast region is fruit and vegetables, thus the shifts in output will be minimal. Additionally, only 6 percent of Williamson Act enrollment is in this region. Due to these factors, little economic activity is expected to be lost in the South Coast region if the Williamson Act was removed.

Table 16: Impact Summary South Coast Low Scenario

\begin{tabular}{l|r|r|r|r}
\hline Impact Type & $\begin{array}{c}\text { Employment } \\
\text { (Jobs) }\end{array}$ & Labor Income (\$) & Value Added (\$) & Output (\$) \\
\hline Direct Effect & -3.2 & $-559,003$ & $-855,426$ & $-1,544,933$ \\
Indirect Effect & -2.4 & $-88,954$ & $-190,185$ & $-329,026$ \\
Induced Effect & -2.2 & $-75,374$ & $-179,076$ & $-268,479$ \\
\hline \hline Total Effect & -7.7 & $-723,331$ & $-1,224,687$ & $-2,142,438$ \\
\hline
\end{tabular}


Table 17: Impact Summary South Coast High Scenario

\begin{tabular}{l|r|r|r|r}
\hline Impact Type & $\begin{array}{c}\text { Employment } \\
\text { (Jobs) }\end{array}$ & Labor Income (\$) & Value Added (\$) & Output (\$) \\
\hline Direct Effect & -8.6 & $-1,664,289$ & $-2,512,754$ & $-4,358,193$ \\
Indirect Effect & -6.5 & $-250,270$ & $-516,579$ & $-852,872$ \\
Induced Effect & -6.4 & $-222,759$ & $-529,278$ & $-793,495$ \\
\hline \hline Total Effect & -21.5 & $-2,137,319$ & $-3,558,610$ & $-6,004,561$ \\
\hline
\end{tabular}

The South East region includes two large vegetable and fruit producing regions:

Arroyo Grande and San Luis Obispo. Fruit production accounts for roughly 38 percent of output and vegetable production comprises around 36 percent of agriculture output in this region. This region is the largest producer of vegetables in the County. The production of fruits and vegetables are very labor intensive. This is evident in the anticipated loss in labor income. Shifts in output have a larger effect on the labor income in the South East than other regions. This region is also of concern because of Barnard and Lucier's observation regarding urbanization and vegetable production. Because land used to produce vegetables possesses the qualities desired for development, it is assumed it has the largest pressure to develop. This is a concern, considering the South East region accounts for 35 percent of total Williamson Act enrollment. However, Barnard and Lucier also observed commodities with high production intensity and high net returns are often the least affected by urbanization.

Table 18: Impact Summary South East Low Scenario

\begin{tabular}{l|r|r|r|r}
\hline Impact Type & $\begin{array}{c}\text { Employment } \\
\text { (Jobs) }\end{array}$ & Labor Income (\$) & Value Added (\$) & Output (\$) \\
\hline Direct Effect & -6.2 & $-614,272.4$ & $-977,897.1$ & $-1,982,167.0$ \\
Indirect Effect & -3.8 & $-153,060.4$ & $-350,328.8$ & $-697,066.2$ \\
Induced Effect & -3.9 & $-149,039.6$ & $-293,943.4$ & $-473,688.5$ \\
\hline \hline Total Effect & -13.9 & $-916,372.4$ & $-1,622,169.4$ & $-3,152,921.8$ \\
\hline
\end{tabular}


Table 19: Impact Summary South East High Scenario

\begin{tabular}{l|r|r|r|r}
\hline Impact Type & \multicolumn{1}{|c|}{$\begin{array}{c}\text { Employment } \\
\text { (Jobs) }\end{array}$} & Labor Income (\$) & Value Added (\$) & Output (\$) \\
\hline Direct Effect & -16.7 & $-1,816,020.3$ & $-2,808,671.2$ & $-5,285,005.0$ \\
Indirect Effect & -9.8 & $-405,953.8$ & $-893,775.6$ & $-1,706,264.7$ \\
Induced Effect & -11.2 & $-432,960.7$ & $-853,974.0$ & $-1,376,095.7$ \\
\hline \hline Total Effect & -37.7 & $-2,654,934.8$ & $-4,556,420.9$ & $-8,367,365.4$ \\
\hline
\end{tabular}




\section{CHAPTER V}

\section{SUMMARY, CONCLUSIONS AND RECOMMENDATIONS}

\section{$\underline{\text { Summary }}$}

The Williamson Act plays a significant role in San Luis Obispo County, protecting nearly 68 percent of agriculture land. Although the Act's main purpose is to prevent urbanization by providing incentives to landowners, it behaves as more of a tax benefit than a land conservation policy. Removing the Williamson Act's funding would have little to no impact on land use in the county, but instead, may affect the financial strength of agriculture operations. To reflect this outcome, this study estimated the changes in output that would occur if the Williamson Act was removed. The decline in economic activity would not devastate the local economy, but the overall significance of the agriculture industry was apparent. In the San Luis Obispo County model, overall shifts in output ranged from 14 million to 39 million. Between 89 and 240 jobs and 4 million to 13 million dollars in labor income is anticipated to be lost. A shift in agriculture output causes many ripple effects in the economy because of its interrelationships between industries. This study concluded there would be 7 to 21 million dollars lost in added value to the agricultural industry if the loss of the Williamson Act caused reduced agricultural output in San Luis Obispo County.

The regional analysis indicated where the county would see the greatest economic impacts if the Williamson Act was cancelled. The North East region produces the most agriculture output in the county and accounts for 50 percent of Williamson Act 
enrollment. Because of these factors, this region will experience the greatest economic impacts. In both the high and the low scenarios, the North East region accounts for nearly half of the total anticipated loss in output for the County. The South East region is the second largest agriculture producing region in the county and also accounts for 35 percent of Williamson Act enrollment. Thus, this region would experience the second greatest economic loss. The North and South Coast will experience the smallest economic impacts due to limited Williamson Act enrollment and minimal agriculture production.

Table 20: Summary IMPLAN Results by Region

\begin{tabular}{|c|c|c|c|c|c|}
\hline \multicolumn{3}{|c|}{ North Coast } & South Coast & North East & South East \\
\hline \multirow{2}{*}{$\begin{array}{l}\text { Employment } \\
\text { (\# of Jobs) }\end{array}$} & High & -7.8 & -21.5 & -130.9 & -37.7 \\
\hline & Low & -2.9 & -7.7 & -48.0 & -13.9 \\
\hline \multirow{2}{*}{$\begin{array}{l}\text { Labor } \\
\text { Income (\$) }\end{array}$} & High & $-589,030$ & $-2,137,319$ & $-6,674,065$ & $-2,654,935$ \\
\hline & Low & $-200,992$ & $-723,331$ & $-2,323,690$ & $-916,372$ \\
\hline \multirow{2}{*}{$\begin{array}{l}\text { Value Added } \\
\text { (\$) }\end{array}$} & High & $-976,182$ & $-3,558,610$ & $-10,488,528$ & $-4,556,421$ \\
\hline & Low & $-344,715$ & $-1,224,687$ & $-3,757,240$ & $-1,622,169$ \\
\hline \multirow{2}{*}{$\begin{array}{l}\text { Output } \\
(\$)\end{array}$} & High & $-1,786,631$ & $-6,004,561$ & $-18,760,048$ & $-8,367,365$ \\
\hline & Low & $-674,495$ & $-2,142,438$ & $-7,110,410$ & $-3,152,922$ \\
\hline
\end{tabular}

\section{Conclusions}

Although this study anticipates minimal adjustments to output if the Williamson Act is eliminated, the total estimated economic loss is notable. The agricultural industry contributed \$736 million in output to San Luis Obispo County's economy in 2010. Because of the multipliers, the total value of the agriculture industry is substantial. The scenarios analyzed were very conservative in nature, yet, the total economic activity lost was noteworthy. It is especially significant to compare the expected economic activity 
lost to the total annual cost of maintaining the Williamson Act. The direct cost of the Williamson Act to San Luis Obispo County is roughly $\$ 3$ million per year, yet if the Act is eliminated, it is estimated $\$ 14$ to $\$ 39$ million will be lost in agricultural output. Despite conservative adjustments to output, the anticipated economic impacts are far greater than the costs to maintain the funding for the Act. Additionally, the cost of the Williamson Act accounts for less than 1 percent of San Luis Obispo's 2011-2012 budget of $\$ 464.4$ million. Financially supporting the Williamson Act is a symbol of the County Government's support for the agriculture industry. It is also a good investment for the County, as the tax incentive to landowners provides 5 to 10 times its value in direct economic activity.

The ramifications of removing the Williamson Act are highly dependent on the current state of the economy, as well as the provision of other farmland protection policies, such as zoning. As the state of the industry changes, the implication of the removing funding will also change. If commodity prices decrease, farmers and ranchers will be more sensitive to changes in their fixed costs of production because they will be operating on slimmer margins. If farmers were more sensitive to an increase in operating costs, larger adjustments to output would be anticipated. As discussed earlier, the underlying explanation to land conversion is land will be converted to the use that generates the greatest economic return (Libby and Abdalla, 2001). If it were less lucrative to keep land in agriculture production, landowners would be more likely to sell their land for development in locations where zoning and the local resource base (such as water availability) allowed such activity. Additionally, high agriculture land values makes landowners less likely to sell their land for development. 


\section{$\underline{\text { Recommendations }}$}

The results of this study should be viewed as an estimation of the economic consequence of eliminating the Williamson Act. As discussed, these results are highly dependent on the current state of the agriculture industry. Furthermore, the results of this study are representative of San Luis Obispo County, and would differ in another county. San Luis Obispo's agricultural output has increased for the past three years, and high commodity prices will likely make 2012 another record-breaking year. As commodity and land values continue to stay strong, changes to the Williamson Act will not have serious impacts on the local economy. The current economic climate has actually reduced the pressure for development. Over the past four years, investments in development have decreased significantly, and more emphasis is being placed on investing in the agriculture industry. These factors not only limit the likelihood of development, but also lessen the financial burden of increased property taxes. If, however, the agriculture industry took a downturn, the possible impacts of removing the Williamson Act would be significantly different.

The methodology used in this study can be applied to other counties considering the value of the Williamson Act. To strengthen this study, more analysis can be done on determining the shifts in output if Williamson Act's funding is eliminated. Due to the nature of the study, there are a number of limitations to the scope of the results. This study only evaluates the economic impacts of removing the Williamson Act, and does not consider the environmental impacts likely to occur if land was farmed more intensively. As discussed in Chapter 4, other land use restrictions prevent development, but in order 
to mitigate rising fixed costs, landowners could intensify production or produce highervalued commodities that may have environmental impacts. Under these circumstances, there could be significant environmental costs to the County that are not measured in this study. A broader study could be conducted regarding the ecological benefits provided by the Williamson Act. Such benefits might include the value of open space, the value of wild life habitat and reduced soil/dust erosion; as well as the corresponding impacts on air and water quality. As policy makers debate the future of the Williamson Act, such non-market benefits should be studied and considered as a complement to the economic analysis provided here.

Additionally, it is recommended to use the base economic data compiled in this study for future research as the agriculture industry faces changes in the operating environment. The disaggregated agriculture data identifies the agriculture commodities and economic structure of each zip code in San Luis Obispo County, which allows the study to be regionally specific. This model could be used to evaluate other potential threats to the agriculture industry in the County, such as labor and immigration laws, methyl bromide substitutes for strawberries, water quality regulations and pesticide regulations. 


\section{REFERENCES}

Barnard, Charles and Gary Lucier. 1998. Urban Influences and the U.S. Vegetable Industry. USDA, Economic Research Service. November. pp. 32-40.

Brown, Caylyn S. 2008. "A Case Study of the Williamson Act in Tehama County." Unpublished M.P.P Thesis. California State University, Sacramento. pp 9-62.

Brown, Edmund, John Laird, and Derek Chernow. California Farmland Conversion Report 2006-2008. California Department of Conservation , 2011.

California Department of Conservation. "California Codes." Government Code Section 51220- 51223. (accessed May 3, 2011).

California Department of Conservation. "Williamson Act Program-Basic Contract Provision" Questions and Answers. (accessed August 20, 2012).

California Department of Conservation. 2011. "California Farmland Conservation Report 2006-2008." Sacramento, Ca: State of California Department of Conservation Division of Land Resource Protections. pp. 11-108.

California Department of Conservation. 2011. “Assembly Bill 1265 Advisory Statement." Sacramento, Ca: Department of Conservation's Division of Land Resource Protection. pp.1.

California Farm Bureau Federation. 1997. “Agriculture Preservation, Williamson Act Property Tax Calculation.” Governmental Affairs Division. March. Appendix E.

Carter, Harold O., George Goldman, Rob Maus, Terri Sexton, Alvin D. Sokolow, Julie Spezia, David Strong. 1989. "Land in the Balance: Williamson Act, Costs, Benefits and Options (Part 1)."California Department of Conservation, December.

Dean, John B. (1975): “A Panacea that Wasn’t.” Cry California 10.318.

Diaz, Elivia, and Peter Detwiler. 2010. "The Williamson Act: Past, Present, Future." Sacramento, Ca: California Department of Conservation Division of Land Resource Protection Legislative Oversite. pp. 3-14.

Dresslar, John. 1979. "Agriculture Land Preservation in California: Time for a New View.” Ecology Law Quarterly (8:2). pp. 4-25.

Governor's Office of Planning and Research. 2003. "California Land Conservation (Williamson Act)." Sacramento, Ca. Department of Conservation Technical Advisory Document. pp. 3-16. 
Hamilton, Lynn. 2004. "The Economic Impact of California Specialty Crops- A Regional Perspective." Working Paper. AGB Department, Cal Poly State University. November. pp.2-22.

Hansen, Todd. 2011. “Assembly Passes Nielsen Williamson Act Legislation.” Sun Herald (May $24^{\text {th }}$ ) P. 1.

Heimlich, Ralph E. and William D. Anderson. 2001. Development at the Urban Fringe and Beyond: Impact on Agriculture and Rural Land. Economic Research Service, U.S. Department of Agriculture. Agricultural Economic Report No. 803.

Hoag, Warren. "Update on Williamson Act Legislation and Funding Possible Options in Response." San Luis Obispo County Board of Supervisors Regular Session. San Luis Obispo, Ca. 7 June 2011.

Kovacs, Kent F. 2009. “The Timing of Rapid Farmland Conversion Events: Evidence from California's Differential Assessment Program." Paper presented at the Agricultural and Applied Economics Association Meeting, Milwaukee, July 2628. 2009.

Landefeld, J. Steven, and Stephanie H. McCulla. "Wassily Leontief and His Contributions to Economic Accounting." Survey of Current Business 79.3 (1999):9. Expanded Academic ASAP. Web. 1 Sep. 2012.

Legislative Analyst's Office. (2004). Analysis of the Budget Bill-Williamson Act Subventions for Open Space. California's Nonpartisan Fiscal and Policy Advisor, February. pp. 120-123.

Libby, Lawrence, and Charles Abdalla. 2001. "Protecting Famland at the Fringe: Do Regulations Work?" Columbus: Rural-Urban Policy Department of Agricultural, Environmental and Developmental Economics, Ohio State University. pp. 3-113.

Lind, Allan. 2011. “Capital Snapshot for April 2011.” Association of Environmental Professionals (May 3). p. 1-2.

McClusky, Jill and George Goldman. Agriculture in Ventura County, Its Impact on the County Economy. Working Paper No. 783. California Agricultural Experiment Station, Giannini Foundation of Agricultural Economics. November. 1995.

Niblett, Matt and Evan Hanneman. 2004. " The Effectiveness of the 1965 Williamson Act at Patterson, California." Unpublished Senior Project. UC Santa Barbara. pp. $1-14$.

Onested, Jeffrey A. "The Effectiveness of the Williamson Act: A Spatial Analysis." P.h.D. Diss. University of California, Santa Barbara, 2007. VDM Verlag. Print.

Osherenko, Gail, Jeff Onsted, Keith Clarke, Noelle Boucquey, and Kristin Hart. 2006. "Retaining California's Coastal Agricultural Land Through Economic Incentives, Regulation, and Purchase.” University of California, Santa Barbara. pp. 3-72. 
San Luis Obispo Chamber of Commerce. 2011. Community Economic Profile. San Luis Obispo, Ca: Research Department of San Luis Obispo Chamber of Commerce. pp. $1-15$.

San Luis Obispo County Department of Agriculture. 2010. 2010 Annual Crop Report. San Luis Obispo, Ca: Department of Agriculture Weights and Measures. pp. 4-16.

San Luis Obispo County Department of Agriculture. 2011. 2011 Annual Crop Report. San Luis Obispo, Ca: Department of Agriculture Weights and Measures. pp. 4-16.

Schwartz, S. I, David E. Hansen, and T. C. Foin. 1976. "Landowners Benefits from UseValue Assessment Under the California Land Conservation Act." American Journal of Agriculture Economics (58:2). May. pp.170-178.

Schwarzenegger, Arnold, Lester A. Snow, and Bridgett Luther. (2010) "The California Land Conservation (Williamson) Act 2010 Status Report." Sacramento, Ca: California Department of Conservation. pp.20-52.

Sokolow, A. D. 2010. "Budget Cuts Threaten the Williamson Act, California's Longstanding Farmland Protection Program." Cal Ag (64:3). July-September. pp. 118-120.

Sokolow, Alvin D., and Mica Bennett. 2004. "Conserving Agricultural Land Through Compensation." Agricultural Issues Center UC Davis. December. pp 3-12.

Sokolow, Alvin and Nicolai Kuminoff. Farmland, Urbanization, and Agriculture in the Sacramento Region. Paper presented at the Regional Futures Compendium, June. 2000 .

Sokolow, Alvin D. 1989. "Land in the Balance: Williamson Act Costs, Benefits and Options (Part 2)." Department of Conservation, December.

The University of California Agricultural Issues Center. 2009. "The Measure of California Agriculture.” Davis, Ca: Agriculture Issues Center, August. pp. 13516.

The University of California Cooperative Extension. 2012. "Sample Costs to Produce

Fresh Market Broccoli: San Luis Obispo County.” Davis, Ca: Cooperative Extension. pp. 3-16.

The University of California Cooperative Extension. 2012. "Sample Costs to Establish a Vineyard and Produce Wine Grapes: San Joaquin Valley North.” Davis, Ca: Cooperative Extension. pp. 3-21.

The University of California Cooperative Extension. 2011. "Sample Costs to Produce Strawberries: South Coast Region.” Davis, Ca: Cooperative Extension. pp. 3-21. 
The University of California Cooperative Extension. 2010. "Sample Costs to Establish a Vineyard and Produce Wine Grapes: North Coast Region.” Davis, Ca:

Cooperative Extension. pp. 3-25.

The University of California Cooperative Extension. 2008. "Sample Costs to Establish a Vineyard and Produce Wine Grapes, Red Varieties: Lake County." Davis, Ca: Cooperative Extension. pp. 3-23.

The University of California Cooperative Extension. 2008. "Sample Costs to Establish a Vineyard and Produce Wine Grapes, White Varieties: Lake County." Davis, Ca: Cooperative Extension. pp. 3-23.

The University of California Cooperative Extension. 2008. "Sample Costs for Beef Cattle: Cow Calf Operation.” Davis, Ca: Cooperative Extension. pp. 3-11

"Trends: A Cattle Fax Publication for Cow Calf Producers." Cattle Fax: Trends 6.8 (2012): 1-4. Print.

Turrentine Grapes and Wine. 2012. June 2012 Collateral Value Report. Novato, Ca: Turrentine Brokerage. pp. 1-20. 


\section{APPENDIX}

Appendix A: Key Milestones in the Williamson Act's History

1965 AB 2117 (Williamson) creates the California Land Conservation Act. Legislature requires the equalization of local property tax assessments, resulting in higher property tax bills on rural lands.

1966 Proposition 3 amends the California Constitution to allow for the preferential assessment of open space lands.

1967 Legislature adopts the capitalization of income method for assessing contracted lands.

196770 Bills expand the definition of the lands that are eligible for contracts.

1969 Legislature allows contract cancellations, but requires county officials to make findings and landowners to pay cancellation fees.

1970 Legislature passes the California Environmental Quality Act (CEQA). Legislature requires counties and cities to include conservation elements and open space elements in their general plans.

1971 Legislature creates the state subvention program.

Legislature requires county and city zoning and subdivision decisions to be consistent with their general plans.

1974 Legislature authorizes open space easements.

1976 Legislature changes subventions to eliminate direct payments to schools and to emphasize urban prime lands.

Legislature begins to equalize school funding after Serrano decision. Legislature creates Timber Preserve Zones, starting the transfer of timberland out of Williamson Act contracts.

1978 Proposition 13 amends the California Constitution to roll back the Full cash value of property assessments and to limit reassessments.

1979 Legislature caps contracted lands' assessments to their Proposition 13 assessments.

Legislature authorizes conservation easements. 
1981 California Supreme Court limits contract cancellations to "extraordinary" situations. Legislature adopts tighter cancellation rules.

1982 Legislature allows counties to limit contracted lands' assessments to $70 \%$ of their Proposition 13 assessments.

Legislature creates the Farmland Mapping and Monitoring Program.

1984 Legislature limits the subdivision of contracted lands.

1987 Legislature codifies fair market value as the basis for computing landowners' cancellation fees.

1988 Department of Conservation starts its audit program.

1989 Department of Conservation publishes Land in the Balance.

1993 Legislature triples the state subventions for contracted land.

1994 Legislature creates specific standards for compatible uses.

1995 Legislature authorizes agricultural conservation easements, now called the California Farmland Conservancy Program.

1996 Proposition 218 amends the California Constitution to limit local taxes, assessments, and fees.

1998 Legislature creates Farmland Security Zones within the Williamson Act with longer contracts, lower assessments, and other protections.

2008 Legislature reduces the state subventions for contracted land by $10 \%$.

2009 Governor cuts the state subventions for contracted lands to $\$ 1,000$.

Source: Diaz, Elivia, and Peter Detwiler. 2010. "The Williamson Act: Past, Present, Future." Sacramento, Ca: California Department of Conservation Division of Land Resource Protection Legislative Oversite. 
Appendix B: Soil Class Descriptions

Prime Farmland: Has the best combination of physical and chemical features able to sustain long-term agricultural production. This land has the soil quality, growing season, and moisture supply needed to produce sustained high yields. Land must have been used for irrigated agricultural production at some time during the four years prior to the mapping date.

Farmland of Statewide Importance: Is similar to Prime Farmland but with minor shortcomings, such as greater slopes or less ability to store soil moisture. Land must have been used for irrigated agricultural production at some time during the four years prior to the mapping date.

Unique Farmland: Consists of lesser quality soils used for the production of the state's leading agricultural crops. This land is usually irrigated, but may include nonirrigated orchards or vineyards as found in some climatic zones in California. Land must have been cropped at some time during the four years prior to the mapping date.

Farmland of Local Importance: Land of importance to the local agricultural economy as determined by each county's board of supervisors and a local advisory committee. The definitions for this category are detailed in Appendix E of this report.

Grazing Land: Land on which the existing vegetation is suited to the grazing of livestock. This category was developed in cooperation with the California Cattlemen's Association, University of California Cooperative Extension, and other groups interested in the extent of grazing activities.

Urban and Built-up Land: Is occupied by structures with a building density of at least 1 unit to 1.5 acres, or approximately 6 structures to a 10 -acre parcel. Common examples include residential, industrial, commercial, institutional facilities, cemeteries, airports, golf courses, sanitary landfills, sewage treatment, and water control structures.

Water: Is defined as perennial water bodies with an extent of at least 40 acres.

Other Land: Is land not included in any other mapping category. Common examples include low density rural developments, vegetative and riparian areas not suitable for livestock grazing, confined animal agriculture facilities, strip mines, borrow pits, and water bodies smaller than 40 acres. Vacant and nonagricultural land surrounded on all sides by urban development and greater than 40 acres is mapped as Other Land. More detailed data on these uses is available in counties containing the Rural Land Use Mapping categories.

Source: California Department of Conservation . 2011. "California Farmland Conservation Report 2006-2008." Sacramento, Ca: State of California Department of Conservation Division of Land Resource Protections. P. 11-108. 